\title{
2
}

\section{Studying Everyday Practice(s) in the SEM}

My interest in asylum decision-making and particularly in credibility determination began when, as a graduate student in social anthropology, I was an intern in an NGO running a centre for asylum seekers. The centre provided housing, financial support and social care. My job at the centre had no direct involvement with asylum decision-making; nevertheless, the SEM's decisions about the individual asylum seekers were sent to our office. We, the employees working at the centre, would then distribute the written notifications of decisions to the asylum seekers, and would often end up translating decisions for them. When translating those letters, I was repeatedly unsettled by the reasons given for rejecting an asylum application-most of which seemed to be based on the decision-maker finding the claim not credible. This ignited my interest in studying SEM caseworkers' decision-making practices. I wanted to "find out" why so many negative decisions were based on noncredibility and what criteria the decision-makers used to determine whether asylum seekers' claims were credible or not. I wanted to critically engage with these practices.

As social scientists doing qualitative research, we (should) organise our "research in such a way that [...] [we] create the conditions for surprise" (Wagenaar 2011: 243). Hendrik Wagenaar, therefore, argues that ethnography or interpretive qualitative research should be thought of as more of "an extended improvisation than [as] a well-thought-out-in-advance [...] strategy" (ibid.: 241). Hence, this is precisely how I went about doing fieldwork. As I gained ever new insights into my research topic, new analytical questions emerged and I began to re-think and question my original hypothesis-which had been affirmed by the literature I initially engaged with-namely, that 
credibility assessments were arbitrary and based on highly subjective views. Rather, what I came to deal with in this book is how administrative caseworkers come to think, feel, know and act in similar ways and how this generates regularities in administrative practice.

My interest in this book lies with the practice of administrative work in a practice theoretical sense. Following Andreas Reckwitz (2002), I understand "practice" as an assemblage of different elements (see also Schatzki 2002: 71). He writes: "A 'practice' (Praktik) is a routinized type of behaviour which consists of several elements, interconnected to one other: forms of bodily activities, forms of mental activities, 'things' and their use, a background knowledge in the form of understanding, know-how, states of emotion and motivational knowledge" (2002: 249). Bodily activities, according to Reckwitz, include activities such as writing, reading and talking; the things that decision-makers in the SEM do most (2003: 290). For researchers dealing with administrative work, this means that we must pay attention to all these different elements (or as many as possible) that constitute a practice: the "taken-for-granted routines"; the implicit and explicit knowledge "brought to bear on concrete situations"; officials' interactions with each other and other actors; the "informal banter and gossip with colleagues during coffee breaks"; their emotional struggles, motivations, doubts and insecurities; as well as the circulation of documents and ideas (Wagenaar 2004: 644). Hence, it means paying attention to what decision-makers say they do in the fullest sense. We must listen to what decision-makers think they should do, what they experience when they do it, and also look beyond what officials say, at what they do or do not do.

This chapter outlines the methodological approach I developed to do this. I describe how I struggled to-and eventually succeeded in—gaining research access to the SEM and how I went about studying everyday practices in the office. I thereby pay particular attention to the challenges I faced when doing fieldwork, not only in terms of getting research access but also, and more importantly, to the methodological challenges arising from a practice theoretical approach. I discuss the ways in which I dealt with and attempted to overcome these challenges and the methodological limitations that remain.

\section{Getting into the "Black Box"}

Bureaucracies or administrations have frequently been characterised as secretive, opaque entities (Hoag 2011: 82) or as "black boxes" (Eule 2014). Furthermore, according to Weber, "administrative secrecy constitutes a key 
dimension of bureaucratic power" (2013 [1978]: 922). In many ways this is what I encountered during fieldwork, as gaining access to the institution proved challenging. However, once I was in, I experienced a lot of openness and transparency towards me.

Gaining access to the field required stamina. In total, it took me one year to get full research access, and one and a half years before I was able to properly start fieldwork. I first tried gaining access "the formal way" by applying via a formal request to the head of the asylum directorate. However, after months of waiting, my request was declined, the main reason for this being that others had previously already done this kind of research. ${ }^{1}$ With persistence and the help of my supervisor I finally managed to get permission to observe an asylum interview and interview the official. However, after that I was unsure how to continue with my research until, a couple of months later at a national asylum conference, I met one of the officials who had rejected my original research request. I approached him, presented myself to him and asked him to help me "get in", which he did. Thus, in the end it was through him-and in this more informal way-that I eventually gained access to the SEM. With his help and that of a colleague of his, I finally managed to draft a new research proposal that was approved by the directorate and served as a basis for the anonymisation contract I was asked to sign. The contract stipulated that I was only allowed to take anonymised documents out of the office with me, that all kinds of personal data I had would have to be destroyed by a certain date, that I could only sit in on asylum interviews if the asylum seeker gave consent and that I was only allowed to publish my doctoral thesis after it had been checked by the SEM.

Once I had signed this contract and was "truly in", I was surprised by the openness and trust I experienced from officials in different hierarchical positions. I was, for instance, allowed to observe asylum interviews, read and copy case files (as long as I anonymised them), and attend internal team meetings. Once, after a day of analysing and copying random case files, I even appeared to be the last one left in the building at 9 p.m. However, at the same time, I am aware that certain information was deliberately not shared with me. At times, caseworkers confided in me things they (thought they) were not supposed to, but then asked me not to use this information; a request which I, of course, honour.

\footnotetext{
${ }^{1}$ This is how I came to know Jonathan Miaz. Jonathan Miaz is a political scientist who also did research on decision-making in the SEM. Later I met Ephraim Poertner, a human geographer working on similar issues. Jonathan Miaz did fieldwork in the SEM between 2010 and 2012, Ephraim Poertner was there between 2012 and 2014 and I eventually conducted my fieldwork between 2014 and 2015. The three of us have since worked closely together on several occasions (see Affolter et al. 2019).
} 
Despite there being some aspects of decision-making that were not shared with me, I believe the fact that officials were so open towards me is of importance and is something worth stressing. It shows that the officials-contrary to a common assumption held by many critics of asylum decision-makingfeel that most aspects of their everyday work have no need to be hidden. The assumption that caseworkers need to hide their everyday practices stems from a particular view on administrations and on what research on administrations is about. It is based on the premise that caseworkers do not do what they are supposed to do and that research will uncover such "deviant" behaviour; or that bureaucracies and bureaucrats are "evil" and that they would not want to have this "identity" uncovered. Neither of these views reflects my stance on decision-makers in the SEM. Rather, I believe that what is important is precisely that decision-makers are mostly confident that they are doing the right thing. For them, their practices are normal and legitimate-they are the self-evident thing to do. Therefore, they have nothing to hide. Taking this seriously is important for understanding how the SEM, and bureaucratic administrations in general, work.

That decision-makers were open towards me does not, however, mean that they did not sometimes — especially at the beginning of my research—adopt a defensive position in our conversations. In general, such a defensive position is something SEM officials quite often adopt towards outsiders. As Tobias Eule (2014: 104) has shown for German immigration offices, this defensive position arises from the "constant criticism" officials are confronted with in their work: criticism by politicians, political organisations and the media, for example, of the office's decision-making being either too harsh or too lenient (see also Lentz 2014: 197). Thus, my empirical material must be read within this context. My field encounters were influenced by this defensive position in two main ways. First, most SEM officials with whom I interacted seemed to categorise me accurately as a "leftist". Therefore, especially at the beginning, when my interaction partners and I were still in the process of establishing mutual trust, it was mostly the "harsh part" of decision-making, their disbelief of asylum stories and decisions to send people back home which they tried to defend, because this was the part they assumed I would be the most critical of. After a while, however, and this is the second way in which the defensive stance of decision-makers influenced my field encounters, many officials began to regard my work as not just a potential threat, but they began to see it as an opportunity to convey a different image of the institution and of its decision-making practices to the outside (see also Eule 2014: 107). 


\section{“Getting In"... Literally}

At the time of my research, asylum decisions were taken by officials working in the five reception and processing centres (RPCs) mostly located close to Switzerland's "physical borders", and in the eight different asylum units at the headquarters in Bern. I eventually ended up doing research at the headquarters - for the most part in two different units there-and in two of the RPCs. This implied getting in and out of four different buildings in a literal sense, which remained a challenging issue throughout the course of my fieldwork. All four buildings were guarded by security officers based in a glass cubicle adjacent to the first entrance door. Every time I wanted to enter, except for in one of the asylum units where I was given a badge, it was obligatory to present my identity card to the security guards, tell them what institution I was from (the university of Bern) and with whom I was meeting that day. They would then call the person to come and pick me up, because without them the inner entrance door was unassailable. In both RPCs, I was usually left standing in the entrance hall, which always seemed to be overcrowded. There were asylum seekers asking guards for permission to leave, asylum seekers coming back from outside and having to inform the guards of their return, asylum seekers asking for appointments with decision-makers, new asylum seekers arriving, having to register or being body searched, for example. It was different at the headquarters. When I arrived I would always be asked to take a seat in the waiting room to the right. I was never the sole occupant. There would usually be social aid representatives and interpreters waiting to be taken to their respective asylum interviews and occasionally there were other "guests" like myself. While the interpreters often sat chatting together, the social aid representatives, whose role it is to observe asylum interviews from a "neutral perspective" and report on them to the Swiss Refugee Council (see Chapter 3), were mostly preparing for upcoming interviews. This meant they would be reading through the different documents from an applicant's case file, particularly the minutes from the first asylum interview, and taking notes. Social aid representatives usually arrive well ahead of the scheduled interview time because it is only upon registering with the security guards that they receive the documents necessary for preparation.

From this waiting room, one could see over into the glass waiting room on the other side of the guard's cubicle, where asylum seekers waited for their interviews. In this other waiting room there was a small playing area where children - in the company of an adult - could play while they waited for their parents to come back from their interviews. Outside the first entrance door at the SEM headquarters there was a sign stating that all asylum seekers had 
to enter through a separate door on the left and register on the left side of the security guard cubicle. Both on the left and on the right side there were inner doors passing the guards' cubicle that could only be opened with security badges. On the first day of training for new SEM employees which I was allowed to participate in, we were told that the purpose of having two separate outer entrance doors and two inner doors was in case of "an applicant becoming aggressive" the doors could be locked separately, thus, trapping the person in between the left outer and inner door. For this reason, SEM employees were advised to always use the doors on the right in order to not get accidentally trapped between two locked doors with an applicant. ${ }^{2}$

From a methodological standpoint, not being able to enter the buildings on my own had both advantages and disadvantages. While it sometimes made me feel like a burden for the decision-makers-having to drag them out of their offices to come and pick me up downstairs — and limited my ability to move around freely between the different buildings, it also meant that I always had to be in the company of someone, which for anthropological research is, of course, very useful.

\section{Doing Fieldwork}

"You don't do fieldwork, fieldwork does you", Bob Simpson's supervisor once counselled him after he complained about being "manipulated by [a] principal informant" (2006: 125). This nicely shows that we do not just choose our interaction partners, sites and moments during fieldwork, but that they also choose us (see Sökefeld 2006: 24). Martin Sökefeld, therefore, speaks of fieldwork as a "social interaction". He writes that, as ethnographers, we often have to surrender control over the research situation to our interaction partners and that only by ceding control to them can we sometimes gain access to yet unknown spheres of social life (ibid.). I will now not only show how I went about doing fieldwork, but also "how fieldwork did me".

I conducted fieldwork in the SEM between 2014 and 2015 (with some exploratory parts in 2013). Where I carried out my research was more or less decided for me. The person who initially helped me gain research access to the SEM-who was at the time in charge of the office's quality management-asked around amongst the heads of the different asylum units at the headquarters and the RPCs who would be willing to have me. Four heads agreed to this and I was put in contact with them to plan my individual

\footnotetext{
${ }^{2}$ Training instructor, A-modules, field notes, my own translation.
} 
field-stays. It was agreed that the individual stays would be relatively short so as not to unduly burden the officials, who worked under a great deal of time pressure. The units at the headquarters each allowed me to stay for two consecutive weeks. I could only go to the two RPCs for one or two days at a time, but they allowed me to do so on five different occasions. In addition to this, I visited other divisions and asylum units of the SEM to sit in on asylum interviews, carry out interviews with SEM officials, analyse case files and take part in the three-week training course for new employees. Furthermore, I met with caseworkers every so often for lunch or a drink outside work.

\section{Following People Around}

During my time in the different asylum units, I accompanied officials in their daily work, observing what they were doing, asking them about what they were doing, listening to their explanations and occasionally also actively joining in their activities (see also McDonald 2005; Mugler 2019: 54; Müller 2017). I now describe the various aspects of the SEM officials' job that I was able to observe in more detail.

Asylum interviews constitute an important part of officials' work. By following caseworkers around, I was able to sit in on eighteen asylum interviews: six initial short asylum interviews and twelve longer second (or third) interviews (see Chapter 3). Usually, a day or two before the interview, the official in charge would give me the case file so that I could read it and make copies of it before the interview. Often, we would then also discuss the 'case' together which could mean different things. ${ }^{3}$ Some decision-makers, for instance, told me what decision they thought they would end up taking before the interview, and why, while others explained to me how they had prepared for the interview or planned to do so. In the case of "old stagers", this was often merely that they had looked through the case file, read through the minutes of the first asylum interview and made a couple of notes. However, some of them-as well as many of the newer employees-showed me elaborate lists of questions they had prepared, and in some cases even chronological diagrams they had made with all the information they already had on a 'case'. On four occasions, I was also able to sit down and prepare the interviews together with the caseworker. Together we went through the different documents in the case file, listing possible questions, which I was also sometimes asked to contribute to, or at least to comment on.

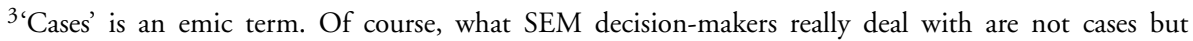
people whose lives are greatly affected by their practices and decisions.
} 
On the day of the interview itself, I would usually accompany the decision-makers to pick up the asylum applicants, interpreters and social aid representatives from their respective waiting rooms. Mostly we would then all walk back to the caseworkers' office in silence, but sometimes some of the actors engaged in friendly conversation with one another. In the decisionmaker's office, we would then all take our assigned places. I was always assigned a place away from the square table around which the asylum seeker, the SEM official, the interpreter and the social aid representative sat. Usually, I was placed behind the minute-taker's desk which allowed me to see onto the computer screen and to observe what was written down during the interview. During the actual interview my role was strictly limited to that of observer. However, of course, this does not mean that my presence did not influence the others. I sat there, listened, observed and took notes. I soon gave up trying to write down everything that was said during the interviews because the conversations were usually too fast for me to get everything down on paper and because I always got a copy of the minutes at the end anyway. Instead, I made notes of my other observations. These included things that were said but not written down by the minute-taker-on their own account or because they were instructed not to do so by the decision-makers-different actors' demeanour, displayed emotions (as I interpreted them), the setting of the room, material being used and passed around as well as my own impressions and sentiments. I never said anything in these interview situations except for the few times I was asked to present myself at the beginning of the interview in order to ask for the applicant's consent to my being there. Normally, however, the decision-makers did this for me, either presenting me as someone from the university who was there to observe them work or as someone who was training for the job. In two of the initial short interviews I sat in on, in which there are no minute-takers, as the minutes are written by the caseworkers themselves, I was asked to write the minutes. The caseworker carrying out the interview sat next to me, at times instructing me on what to write.

During breaks in asylum interviews, I usually waited for the decisionmaker to come back from taking the other participants to their respective waiting rooms and in the meantime chatted with the minute-takers who often shared their views on the particular 'case' with me or on the decisionmaker carrying out the interview. When the caseworkers came back, I normally asked them about their first impressions and how they planned on proceeding.

Asylum interviews - especially those lasting a whole day-are exhausting, even for me, as someone who did not have an active role. Therefore, the 
decision-makers and I rarely engaged in long conversations after the interview had finished. Normally, the caseworkers printed out the minutes for me and we would arrange to meet a day or two later to discuss the 'case'. Sometimes, by then the decision-makers had already started writing the decision and they showed me the arguments they had developed so far. But mostly they just told me what they thought their decision was going to be-and why they were going to take that particular decision-as well as how they planned on proceeding. I was also repeatedly asked to give them feedback on how they had carried out their asylum interviews because the caseworkers thought I might have some interesting insights from also having observed some of their co-workers do interviews. Because most decisions had not been finalised by the time I left the units, I was allowed to write down the number of the 'cases' and contact the secretaries of the different units on a regular basis to ask if the decisions had been sent out, and then pick up copies of the final decisions when they had been. ${ }^{4}$

It should be noted that the asylum interviews I attended during fieldwork were not completely random. In the first instance, it depended on whether the caseworkers would allow me to sit in (they did not allow me to in only two cases). Furthermore, I was not permitted to attend any GespeVer (genderbased persecution) interviews, which are mainly 'cases' in which the claimants have experienced sexual violence or were persecuted on the grounds of their sexual orientation. As a woman I would only have been permitted to attend interviews with female applicants, and there were only a few during my stay. Furthermore, the heads of the asylum units feared that my presence could make the situation even more unbearable for the applicants - these interviews tend to be particularly intimate-so I was excluded from them and I never pushed to be allowed to sit in.

In addition to sitting in on asylum interviews, accompanying officials in their daily work involved sitting in their offices and observing them carry out different tasks: writing decisions; writing letters to applicants; reading reports about different "countries of origin"; writing answers to interpellations which had been passed down the institution's hierarchy and had ended up on their desks; dealing with family reunification requests as well as giving advice to co-workers or asking for advice from them. In these situations, the officials mostly treated me as a novice, explaining what they were doing step by step. They also often printed out the documents they were working on for me so that I could follow better. The same also happened on the days in which I followed the heads of asylum units around. On those days, I was

\footnotetext{
${ }^{4}$ I was also able to trace decisions that were appealed at the Federal Administrative Court, where I was given permission to study the case files under supervision and make notes of them.
} 
able to observe superiors assign new asylum 'cases' to their employees as well as check the latter's decisions before sending them out to asylum seekers. Furthermore, many people kept stopping by or phoning the heads' offices to discuss various issues, which allowed me to observe interesting interactions. Twice I was also able to sit in and observe so-called "consultation meetings" between a superior and a caseworker in which they discussed specific 'cases' and how the caseworkers should proceed with them. Decision-makers can ask for such meetings if they feel that they need help with a particular 'case'. Furthermore, one superior let me observe him prepare his staff appraisals and to also sit in on one of the appraisal interviews. Lastly, two heads took me to meetings with them: one to an internal meeting of the asylum unit he was in charge of, and one to a division meeting attended by the heads of different asylum units.

During my field-stays, I was usually assigned an office; a place where I could write down my notes and anonymise all the documents I had received. While I never spent much time in my office, having one nevertheless proved helpful for fieldwork. Firstly, because in the SEM, hallways are busy places and caseworkers tend to leave their office doors open. Thus, by just sitting in "my office" I was able to overhear several interesting conversations: caseworkers telling their colleagues about an asylum interview they had just done or were in the middle of doing, caseworkers asking their co-workers for help with a decision or caseworkers jointly looking for arguments to prove the non-credibility of a claim, for instance. The one time I shared an office with three decision-makers, this coming and going was even more easily observable. Furthermore, after a while, decision-makers would just come to my office to talk to me and to tell me about 'cases' they were working on.

Finally, taking the morning coffee break together was common practice in the asylum units. These breaks turned out to be particularly fruitful moments of fieldwork. Sometimes, the conversations during breaks were completely unrelated to work and so I learnt quite a bit about the decision-makers' private lives. Often, however, they would discuss specific 'cases' or aspects of their work-particularly if they were unhappy with them-allowing me to learn a lot about the office.

\section{Method Triangulation}

In addition to following people around, observing them and talking to them in and about their everyday work, I conducted interviews with twenty-seven caseworkers from nine different asylum units. Thus, in addition to caseworkers from the units in which I did fieldwork, I also interviewed officials I 
met during the induction training; officials I was put in touch with by other decision-makers; that I met by chance during one of my field-stays; or that I already knew from before my research. I was able to interview two of the new employees that I met on two occasions. The first, when they had only been working at the SEM for a couple of weeks or months, and the second time after they had been working there for a little over a year. I usually prepared some questions before the interviews and developed preferences for a couple of questions I found worked well in most situations. But, mostly, I proceeded in a very open way in order to see what my interaction partners considered to be important topics (see Wagenaar 2011: 253). I asked officials about observations I had made, asking for explanations and clarifications as well as their reflections on them. Without much probing from my side, decision-makers often started telling me specific "stories" or describing particular 'cases' which then repeatedly led them to search for and show me the specific case file, if it was still in their possession. Such narratives, according to Steven MaynardMoody and Michael Musheno, are very useful for gaining an understanding of the "normative reasoning and context" that shape administrative work. Thus, they write that

[w] hen examining moral responsibility, especially when it is deeply embedded in the normative structures of institutions and policy regimes, we cannot expect people, whether frontline staff or upper-level managers, to articulate their actual decision norms. Narratives, on the other hand, provide rich evidence of the normative reasoning and context that shape judgements and actions. Through narratives, storytellers reveal more than they consciously know. (2012: 21)

My interviews, which I recorded either in writing or via audio and later transcribed, include "stories", biographical accounts, normative reflections and abstract descriptions of everyday practice. I often, rather subconsciously at the time, pushed for detailed descriptions of officials' work, asking over and over again why and how they did certain things, which frequently led decision-makers to tell me that there were certain aspects of their work that simply could not be explained: these were things they just did or knew, without being able to put them into words. In hindsight, these questions have proven helpful for discerning decision-makers' implicit knowledge-the things they just know and do without being able to discursively explain why and how-and the taken-for-granted, self-evident aspects of their everyday work.

Another important method I made use of was document analysis. As mentioned above, in my interactions with SEM officials, I was often given 
copies of the documents they were working on or working with, such as training materials, so-called country of origin reports, internal guidelines on how to deal with applications by people from specific countries, news reports or drafts of asylum decisions, for example. Furthermore, I was able to photocopy and analyse the content of seventy-two case files. Thirteen of these files came from 'cases' I had come into contact with during my fieldwork and in which I had sat in on the corresponding asylum interviews. The remaining fifty-nine case files were from when I was granted access to nearly all the files of 'cases' that had been decided upon by decision-makers from all of the SEM's asylum units on two randomly set dates. Hence, in many of these 'cases' I do not know the decision-makers personally, nor was I present when these 'cases' were dealt with in practice. Nevertheless, they allowed me to get a good overview of the different types of asylum decisions that are made, the different kind of enquiries undertaken by the decision-makers (see Chapter 3) and the different kinds of documents that exist in the SEM.

This "method triangulation" (Hammersley and Atkinson 2007: 184) was crucial for my research for two connected reasons. First, because the data generated through these different methods shed light on decision-making practices from different angles, allowing me to, for example, analytically approach both discursive and non-discursive aspects of everyday practice in the SEM (see also Dahlvik 2018: 19). Second, the different insights I gained from each of these methodological approaches provided me with new ideas, for instance, on what issues to inquire into, what moments to pay special attention to during my observations, what documents to look for, or what questions to ask my interaction partners. In this regard, I gained particularly fruitful insights during the three weeks I was able to participate in the induction training for new SEM employees (see Chapter 5).

\section{The Researcher as a Learner}

When "studying an unfamiliar setting" we are, at least at the beginning, always novices (Hammersely and Atkinson 2007: 80). However, as Martyn Hammersley and Paul Atkinson argue, there is an essential difference between what they call "lay novices" and ethnographers, in that "the latter attempts to maintain a self-conscious awareness of what is learned, how it has been learned, and the social transactions that inform the production of such knowledge" (2007: 80). This is precisely what I attempted to do while participating in the trainings for new asylum decision-makers in the SEM.

Being a learner or a novice is, of course, a role we as ethnographers occupy beyond such specific learning situations. In general, it is a helpful 
role because we often want the people we are working with to teach us about their "everyday worlds" (see Le Compte et al. 1999: 21-22). However, at the same time, it is also important to maintain a balance between ignorance and expertise (see also Hammersley and Atkinson 1995: 103). This appears to be particularly important when studying organisations and "professional worlds" where, as Johanna Mugler argues, researchers must "acquire a considerable amount of expert knowledge" in order "to be taken seriously" by the people we are working with (2019: 65). The training sessions in the SEM constituted an important setting for me in order to acquire this necessary expertise. But they were also unique learning situations in other ways.

What made the training sessions special and, to some extent, also quite challenging was that I was not the only learner there. Except for the trainers, everybody else present was also learning. With regard to my relationship with the other participants this meant that I could not really "be taught" by them, which seemed to make it more difficult to establish a rapport with them. In comparison with the rest of my field-stays, I experienced less openness towards me and less interest in my research endeavours. Some even seemed a bit suspicious of me, but most of them were simply very busy learning new tasks, getting to know their co-workers, and growing used to their new daily routines. The best moments for engaging in conversation with the trainees were, therefore, when we had to work together in groups and try to apply the aspect of law we had just learnt about to specific 'cases'. In those moments I "truly" became a participant like the others and often refrained from taking field notes.

It was also in these moments that I gained the most valuable insights into decision-makers' learning processes: into what they found easy, difficult, surprising or disturbing, for example; into the knowledge and experience they brought with them to the job; into how the different training materials were used and referred to during "practical exercises"; into the questions the trainees posed to their trainers; and the aspects of the job-or rather of the practical exercises we did-that they seemed to struggle with most. But not only was I able to observe how others were learning, I also tried to selfreflexively take notes of my own experiences during the training sessions. The following entry from my fieldwork diary illustrates this:

I feel just like yesterday. I'm shocked by what these exercises trigger in me. It's really exiting to finally be able to apply the law and to see in each 'case' whether I managed to get it 'right' or 'wrong'. The more complex a 'case', the 
more interesting it becomes. Looking around me, I don't think I'm the only one that feels that way. ${ }^{5}$

It was, amongst other things, observations like these that got me interested in how certain practices become "normalised" for decision-makers, helping me shape my analytical research questions. Furthermore, the training materials I received and the notes I took during those three weeks helped me a great deal to get an idea of the regulatory constraints and conditions of asylum decision-making, the different steps of the formal proceedings as well as of the documents and artefacts available for and used in decision-making. They also allowed me to better understand what it was that people were doing during my subsequent field-stays, and to be able to ask more specific questions.

\section{My Interaction Partners in the SEM}

Fitting with practice theory, the personalities of the officials I interacted with do not figure prominently in my work. I marginally deal with their educational backgrounds and their motivations for doing the job in Chapter 5. But other than that, for my analysis with its focus on situated practice and on institutional socialisation and learning processes, what is mainly relevant is decision-makers' "position" within the organisation and their professional experience. What was important for my research was, therefore, to include both experienced caseworkers and those who were still quite new to the job, as well as people holding different hierarchical positions, in my sample of interaction partners in the SEM. In the end, nine of my thirty-one interaction partners were "old stagers", meaning that they had worked at the SEM for fifteen years or more. Seventeen of my interaction partners had only been working at the SEM for three years or less at the time I met them. These seventeen all considered themselves to be "quite new to the job" and still had temporary working contracts. In contrast, only five of my interaction partners had been working at the SEM between four and fourteen years and, with the exception of one, all held higher hierarchical positions. This fits with the assessment of several of my interaction partners (all of them "new" employees) that after roughly five years on the job, it was either time to leave, or to move up the hierarchy. In addition to these four officials, three of the "old stagers" I interacted with also held higher hierarchical positions.

As can be seen, the percentage of "new" employees with fixed-term contracts in my sample was quite high, for which there seem to be several

\footnotetext{
${ }^{5}$ Field notes, my own translation.
} 
reasons. Firstly, it has to do with the fact that in general, at the time of my fieldwork, there were many "new" caseworkers in the SEM. The SEM's asylum directorate had significantly grown in the years previous to my fieldwork and many new decision-makers had been employed in an attempt to reduce the number of pending cases (see Chapter 3). Secondly, it was often easier for me to approach and establish rapport with new employees. On the one hand, this was related to new employees mostly being the same age as me and having a similar educational background (see Chapter 5). On the other hand, they tended to be more physically present in the office. They normally came to the coffee breaks in the morning (whereas quite a few "old stagers" did not) and spent the working days in their offices (whereas quite a few "old" employees were allowed to sometimes work from home or had special tasks which at times took them away from the office). Thirdly, in many asylum units where I did my fieldwork, the superiors decided with whom I would be spending time. I do not know if the superiors always approached specific employees or just asked around who would be willing to "have me". However, I think there are again two probable reasons why I was more often sent to new employees than to their experienced co-workers. On the one hand, I know that two of the "old stagers" that had been approached by the superiors told them that they did not want me to accompany them in their work. Of course, it is also possible that some of the new employees refused my company, and that I am simply not aware of this. Nevertheless, based on my observations, I assume that for new employees it was more important to get the approval of their superiors (who had agreed to receive me and now needed a place for me to be every day) and, therefore, did not want to deny their superiors' request. This might also relate to the fact that new employees hold fixedterm contracts and, thus, getting into (or remaining in) their superiors' good books is crucial for them. On the other hand, it could also be that the superiors directly approached more new employees who, not having been on the job very long, were often less behind with their work than their "older", more experienced colleagues who had accumulated much bigger workloads. Thus, they had more time for me.

\section{Thinking Through and with Practice Theory: Methodological Limits and Challenges}

In this final part of the chapter, I address the methodological challenges and limits of grasping everyday practices through ethnography. As stated above, I find a practice theoretical understanding of practice useful because, as Russel 
Hitchings writes "[ $t]$ his area of scholarship has had some of the most to say about the relatively habitual ways in which we all pass through much of our lives" (2012: 61). I argue that this also applies to many of the things administrative caseworkers do. It should be noted here that it was through my "data", through the observations I made in the SEM, that I arrived at practice theory-which seemed the most useful for analysing my empirical material—and not the other way around. I therefore "use" theory in the way proposed by Hendrik Wagenaar who, drawing on Barney Glaser and Anselm Strauss (1967) writes that " $[\mathrm{t}]$ heory is not a final statement about some social phenomena or activity but a 'strategy for handling data' [...]: provisional, open-ended, but always restrained by what the world tells us" (Wagenaar 2011: 260).

Following Andreas Reckwitz's suggestion, decision-makers' "bodily activities", such as writing, reading and talking to each other, their implicit practical knowledge and everyday routines, are at the centre of my analysis. Furthermore, I am interested in how decision-makers' "professional subjectivities" are shaped by their surroundings: the regulatory constraints posed by the organisation, the type of bureaucratic decision-making work they do as well as the laws and policies they must "apply" within the ideological environments they work. I inquire into how decision-makers come to think, act and know things in similar ways, but also how they develop similar understandings of what is moral, ethical and desirable. For this purpose, I draw on Pierre Bourdieu's concept of the habitus, as outlined in the introduction (see Bourdieu 1976). Similar to Bourdieu, Andreas Reckwitz argues that the "conventionalized 'mental' activities of understanding, knowing how and desiring are necessary elements and qualities of a practice in which the single individual participates, not of the individual" (2002: 250). Thus, individuals — in my case SEM officials — become "carriers" of certain practices (ibid.). However, this does not mean that the (institutional) habitus works in a deterministic way or that, as Russel Hitchings claims, "individuals always bow automatically to the dictates of the practice" (2012: 62). Practice also allows for and requires improvisation (see Bourdieu 1990; Shove and Pantzar 2007).

Not everything we do is verbalisable. Rather, some things we do, like cooking or skiing for example, are partially non-linguistic (see Bloch 1991: 189; Martens 2012). This has led some authors to argue that "talk" is not enough to understand practices and that we need to also make use of other qualitative (or even quantitative) methods to be able to more fully comprehend practices (see Browne 2016; Halkier and Jensen 2011; Martens 2012). I agree with these authors that not everything can be expressed through "talk" and that-depending on the research questions we pose (see Shove 2017) _ method triangulation may indeed make sense to approach practices from 
different angles. Nevertheless, following Russel Hitchings (2012), I argue that we also should not underestimate the things that can be verbalised and what we can learn from talking to our interaction partners. As human beings, we are able to reflect on the things we do and to some extent also the things that make us do what we do. We are often even used to doing so. Talking to people during fieldwork, also but not exclusively through doing interviews with them, can, therefore, be useful for learning about such reflections. Furthermore, in retrospective, our interaction partners are usually also capable of telling us about how certain things went, what they did and how they felt in those moments. And conversations can also tell us a lot about norms, rules and principles (see Browne 2016) which, as I will show in this book, are crucial for understanding asylum decision-making.

SEM officials reflect a lot upon the work they do. They have their own theories about what they do, why they do it and what a critical analysis of their work should be about. I learnt a great deal from those theories. Nevertheless, I believe that as anthropologists it is equally important to maintain a critical distance from these theories and interpretations and to not just unquestioningly make them our own. On the contrary, it might sometimes be more fruitful for us as researchers to look at those aspects of what we are studying that our interaction partners have no theories about; the things that are just normal and self-evident to them. However, when doing fieldwork, we also become inured to such normalities. Consequently, Cris Shore and Susan Wright claim that it is important to "maintain sufficient critical distance to be able to keep asking fundamental questions about how [our interaction partners] conceptualise their worlds and what this means for theoretical debates" (2011: 15). In my case, doing fieldwork so "close to home" helped maintain this critical distance because I never completely left my academic surroundings and also during fieldwork, I kept discussing my findings with colleagues. Furthermore, the collaborative work I did with Jonathan Miaz and Ephraim Poertner, the other two researchers working on decision-making in the SEM, also proved to be useful in this regard in that it helped me uncover some of my "blind spots". At the same time, I am sure that other blind spots remain.

\section{References}

Affolter, Laura, Jonathan Miaz, and Ephraim Poertner. 2019. “Taking the 'Just' Decision: Caseworkers and Their Communities of Interpretation in the Swiss Asylum Office." In Asylum Determination in Europe: Ethnographic Perspectives, edited by Nick Gill and Anthony Good, 263-284. Cham: Palgrave Macmillan. 
Bloch, Maurice. 1991. "Language, Anthropology and Cognitive Science." Man (New Series) 26 (2): 183-198. https://www.jstor.org/stable/pdf/2803828.pdf, last accessed March 13, 2020.

Bourdieu, Pierre. 1976. Entwurf einer Theorie der Praxis auf der ethnologischen Grundlage der kabylischen Gesellschaft. Frankfurt am Main: Suhrkamp.

Bourdieu, Pierre. 1990. The Logic of Practice. Translated by Richard Nice. Stanford: Stanford University Press.

Browne, Alison L. 2016. "What Do Mixed Methods Make? Practice Theory, Qualitative and Quantiative Data." Blog Practice Theory Methodologies, April 12. https://practicetheorymethodologies.wordpress.com/2016/04/12/alison-1-bro wne-what-do-mixed-methods-make-practice-theory-qualitative-and-quantitativedata/, last accessed March 16, 2020.

Dahlvik, Julia. 2018. Inside Asylum Bureaucracy: Organizing Refugee Status Determination in Austria. IMISCOE Research Series. Cham: Springer.

Eule, Tobias G. 2014. Inside Immigration Law: Migration Management and Policy Application in Germany. Farnham: Ashgate.

Glaser, Barney G., and Anselm L. Strauss. 1967. The Discovery of Grounded Theory: Strategies for Qualitative Research. New York: Aldine Publishing Company.

Halkier, Bente, and Iben Jensen. 2011. "Methodological Challenges in Using Practice Theory in Consumption Research: Examples from a Study on Handling Nutritional Contestations of Food Consumption." Journal of Consumer Culture 11 (1): 101-123. https://doi.org/10.1177\%2F1469540510391365.

Hammersley, Martyn, and Paul Atkinson. 1995. Ethnography: Principles in Practice. 2nd ed. London and New York: Routledge.

Hammersley, Martyn, and Paul Atkinson. 2007. Ethnography: Principles in Practice. 3rd ed. Abingdon: Routledge.

Hitchings, Russel. 2012. "People Can Talk about Their Practices." Area 44 (1): 61-67. https://doi.org/10.1111/j.1475-4762.2011.01060.x.

Hoag, Colin. 2011. "Assembling Partial Perspectives: Thoughts on the Anthropology of Bureaucracy.” PoLAR: Political and Legal Anthropology Review 34 (1): 81-94. https://doi.org/10.1111/j.1555-2934.2011.01140.x.

Le Compte, Margaret D., Jean J. Schensul, Margaret R. Weeks, and Marrill Singer. 1999. Researcher Roles and Research Partnerships: 6 Ethnographer's Toolkit. Walnut Creek: AltaMira Press.

Lentz, Carola. 2014. "I Take an Oath to the State, Not the Government': Career Trajectories and Professional Ethics of Ghanaian Public Servants." In States at Work: Dynamics of African Bureaucracies, edited by Thomas Bierschenk and JeanPierre Olivier de Sardan, 175-204. Leiden and Boston: Brill.

Martens, Lydia. 2012. 'Practice 'in Talk' and Talk 'as Practice': Dish Washing and the Reach of Language. Sociological Research Online 17 (3): 103-113. https://doi. org/10.5153\%2Fsro.2681.

Maynard-Moody, Steven, and Michael Musheno. 2012. "Social Equities and Inequalities in Practice: Street-Level Workers as Agents and Pragmatists." Public Administration Review 72 (s1): 16-23. https://doi.org/10.1111/j.1540-6210. 2012.02633.x. 
McDonald, Seonaidh. 2005. "Studying Actions in Context: A Qualitative Shadowing Method for Organizational Research.” Qualitative Research 5 (4): 455473. https://doi.org/10.1177/1468794105056923.

Mugler, Johanna. 2019. Measuring Justice: Quantitative Accountability and the National Prosecuting Authority in South Africa. Cambridge and New York: Cambridge University Press.

Müller, Anna-Lisa. 2017. "Does Architecture Talk Back? Researching Architecture's Agency." Blog Practice Theory Methodologies, November 24. https://practi cetheorymethodologies.wordpress.com/2017/11/24/anna-lisa-mueller-does-arc hitecture-talk-back-researching-architectures-agency/\#more-878, last accessed March 16, 2020.

Reckwitz, Andreas. 2002. "Toward a Theory of Social Practices.” European Journal of Social Theory 5 (2): 243-263. https://doi.org/10.1177\%2F1368431022222 5432.

Reckwitz, Andreas. 2003. "Grundelemente einer Theorie sozialer Praktiken: Eine sozialtheoretische Perspektive." Zeitschrift für Soziologie 32 (4): 282-301.

Schatzki, Theodore R. 2002. The Site of the Social: A Philosophical Account of the Constitution of Social Life and Change. University Park, PA: Pennsylvania State University Press.

Shore, Cris, and Susan Wright. 2011. "Conceptualising Policy: Technologies of Governance and the Politics of Visibility." In Policy Worlds: Anthropology and the Analysis of Contemporary Power, edited by Cris Shore, Susan Wright, and Davide Però, 1-25. New York: Berghahn Books.

Shove, Elizabeth. 2017. "Practice Theory Methodologies Do Not Exist." Blog Practice Theory Methodologies, February 15. https://practicetheorymethodolog ies.wordpress.com/2017/02/15/elizabeth-shove-practice-theory-methodologiesdo-not-exist/, last accessed March 17, 2020.

Shove, Elizabeth, and Mika Pantzar. 2007. "Recruitment and Reproduction: The Careers and Carriers of Digital Photography and Floorball." Human Affairs 17 (2): 154-167. https://doi.org/10.2478/v10023-007-0014-9.

Simpson, Bob. 2006. "You Don't Do Fieldwork, Fieldwork Does You': Between Subjectivation and Objectivation in Anthropological Fieldwork." In The SAGE Handbook of Fieldwork, edited by Dick Hobbs, and Richard Wright, 125-137. London: Sage.

Sökefeld, Martin. 2006. "Interaktionspartner im Vergleich: Ali Hassan und Mohammad Abbas in Gilgit." Ethnoscripts 8 (2): 7-29. https://doi.org/10.5282/ ubm/epub.13152.

Wagenaar, Hendrik. 2004. "'Knowing' the Rules: Administrative Work as Practice." Public Administration Review 64 (6): 643-656. https://doi.org/10.1111/j.15406210.2004.00412.x. 
Wagenaar, Hendrik. 2011. Meaning in Action: Interpretation and Dialogue in Policy Analysis. Armonk: M.E. Sharpe.

Weber, Max. 2013 (1978). Economy and Society. Edited by Guenther Roth and Claus Wittich. Berkeley: University of California Press.

Open Access This chapter is licensed under the terms of the Creative Commons Attribution 4.0 International License (http://creativecommons.org/licenses/by/4.0/), which permits use, sharing, adaptation, distribution and reproduction in any medium or format, as long as you give appropriate credit to the original author(s) and the source, provide a link to the Creative Commons license and indicate if changes were made.

The images or other third party material in this chapter are included in the chapter's Creative Commons license, unless indicated otherwise in a credit line to the material. If material is not included in the chapter's Creative Commons license and your intended use is not permitted by statutory regulation or exceeds the permitted use, you will need to obtain permission directly from the copyright holder. 